\title{
Plasma concentrations of oestradiol-17 $\beta$ and progesterone, and laparoscopic observations of the ovary in the puma (Felis concolor) during oestrus, pseudopregnancy and pregnancy
}

\author{
Rosemary C. Bonney, H. D. M. Moore and D. M. Jones \\ Institute of Zoology, The Zoological Society of London, Regent's Park, \\ London NW1 4RY, U.K.
}

\begin{abstract}
Summary. Plasma levels of oestradiol and progesterone in 3 pumas during oestrus and artificially induced pregnancy and pseudopregnancy were determined by radioimmunoassay. During oestrus, basal levels of oestradiol $(5-30 \mathrm{pg} / \mathrm{ml})$ were interrupted by surges of $30-375 \mathrm{pg} / \mathrm{ml}$ at intervals of $17-25$ days. Considerable variation occurred between and within animals. Periods of oestrus and follicular development were confirmed by laparoscopy and vaginal smear patterns. Absence of an increase in plasma progesterone following elevated levels of oestradiol and failure to observe corpora lutea in the ovary indicated that ovulation was probably not spontaneous.

Plasma oestradiol values rose dramatically in response to PMSG but were low during pseudopregnancy until the return to oestrus. During pregnancy surges of oestradiol occurred at mid-term and immediately before parturition. Ovulation, confirmed by laparoscopy, occurred 24-48 h after hCG and progesterone levels (usually $<2 \mathrm{ng} / \mathrm{ml}$ ) then increased to reach $150-300 \mathrm{ng} / \mathrm{ml}$ on Days 24-28. In the pseudopregnant animals progesterone concentrations had returned to baseline by Days $45-50$ but during pregnancy progesterone remained elevated, declining only gradually to basal values by Day 85 . A minor peak of progesterone, coincident with the pre-partum oestradiol surge, occurred on Day 87, 1 week before parturition on Day 95.
\end{abstract}

\section{Introduction}

Many wild felids, for example the cheetah (Acinonyx jubatus) and the snow leopard (Panthera uncia), are now threatened with extinction and may well depend on breeding in captivity for their survival. With the exception of the lion (Panthera leo) (Schmidt, Nadal, Schmidt \& Beamer, 1979) and the jaguar (Panthera onca) (Wildt, Platz, Chakraborty \& Seager, 1979), there is little specific information on reproduction in any species of large cat. Such knowledge is, however, vital to our understanding of felids as a group and to the development of their artificial breeding in zoos.

The domestic cat is the only species which has been studied in detail: these cats are seasonally polyoestrous and coitus (Concannon, Hodgson \& Lein, 1980) or an equivalent stimulus, for example, cervical stimulation (Greulich, 1934) or gonadotrophin administration (Wildt, Kinney \& Seager, 1978), is necessary to trigger ovulation. In the absence of an ovulatory stimulus successive periods of oestrus occur, but if ovulation is induced without fertilization 
taking place an extended luteal phase or pseudopregnancy prolongs the interoestrous interval. Hormonal profiles for oestradiol and progesterone during oestrus, pregnancy and pseudopregnancy have been described (Paape, Shille, Seto \& Stabenfeldt, 1975; Verhage, Beamer \& Brenner, 1976) and plasma oestradiol levels have been correlated with vaginal cytology and behavioural observations (Shille, Lündstrom \& Stabenfeldt, 1979). The only parallel study for a wild felid is that by Schmidt et al. (1979), who reported patterns of plasma oestradiol and progesterone concentrations during the oestrous cycle and in normal pregnancy in the lion: behavioural observations and vaginal cytology were correlated with hormonal changes and the results indicated that spontaneous ovulation is a frequent event but that anovulatory cycles can also occur. A similar observation was reported for the lion by Seal, Plotka \& Gray (1978).

The aim of the present study was to investigate hormonal changes associated with artificial breeding in the puma (Felis concolor). This species was selected because it has a good breeding record in captivity, is relatively easily available and is a convenient size.

\section{Materials and Methods}

\section{Experimental animals}

Three mature females, two of proven fertility, and one male puma were used in the study. The animals were housed in separate dens in the Animal Hospital under natural and subdued artificial light and at temperatures of $15-20^{\circ} \mathrm{C}$. All 3 females were used for monitoring oestrus and its cyclicity. Induction of ovulation without artificial insemination was carried out in two pumas (B and $C$ ) to provide data for 3 pseudopregnancies. Attempts were made to inseminate 3 females on 4 occasions, but only one successful pregnancy was achieved. Investigations were carried out throughout the year, the pumas at London Zoo being non-seasonal breeders (unpublished data).

Sedation and anaesthesia. Sedation for collection of blood samples and vaginal smears was achieved by i.m. injection of a mixture of ketamine (Vetalar: Parke Davis, Pontypool, Gwent, U.K.), $5 \mathrm{mg} / \mathrm{kg}$ body weight, and xylazine (Rompun: Bayer U.K. Ltd, Bury St Edmunds, Suffolk, U.K.), $0.5 \mathrm{mg} / \mathrm{kg}$ body weight. Initially this dose was adequate for light sedation but with repeated treatment the animals became resistant to these drugs and higher quantities (up to $10 \mathrm{mg}$ ketamine $/ \mathrm{kg}$ ) were required. However, the procedure was continued 3 times weekly over periods of up to 3 months without apparent ill effects.

Anaesthesia for laparoscopy, electroejaculation and insemination was induced by i.v. administration of thiopentone sodium (Pentothal: May \& Baker Ltd, Dagenham, Essex, U.K.), $5 \mathrm{mg} / \mathrm{kg}$ body weight, and when necessary the animals were intubated and maintained on a halothane/oxygen mixture.

Collection of blood samples. Blood $(10-20 \mathrm{ml})$ was withdrawn three times weekly from the jugular or cephalic vein, transferred to a heparinized tube and centrifuged immediately. Plasma was stored at $-20^{\circ} \mathrm{C}$ until analysed.

Vaginal smears. Vaginal smears were taken as gently as possible from sedated animals by using a sterile swab moistened with saline. After collection the smears were fixed with $1 \%$ polyethylene glycol in alcohol containing $2 \%$ water and $0.5 \%$ glacial acetic acid, and stained according to the Papanicolaou method (see Lillie \& Fullmer, 1976). The degree of cornification of the vaginal epithelium was assessed by calculating the percentage of cornified cells present.

Laparoscopy. Laparoscopy examinations were performed under anaesthesia using a 5 or 10 $\mathrm{mm}$ diameter fibre-optic laparoscope fitted with an adaptor to permit photography (Richard Wolf Ltd, Knittlingen, West Germany). The animals were examined in a supine position with the head down at an angle of $20-30^{\circ}$ and were insufflated with 2-3 litres nitrous oxide.

Induction of ovulation. The regimen for induction of ovulation was similar to that previously used for the lion (Rowlands \& Sadieir, 1968). PMSG (1250 i.u.: Folligon: Intervet Laboratories Ltd, Bar Hill, Cambs, U.K.) was administered i.m. to females in dioestrus when circulating levels 
of oestradiol- $17 \beta$ were low $(10-30 \mathrm{pg} / \mathrm{ml})$ in order to minimize the risk of superovulation. This was followed $72 \mathrm{~h}$ later by i.m. injection of $1000 \mathrm{i} . \mathrm{u}$. hCG (Chorulon: Intervet). Maturation and rupture of ovarian follicles was monitored by laparoscopy.

Collection of semen. Semen was collected from the anaesthetized male by electroejaculation with a bipolar rectal ring probe $(3.5 \mathrm{~cm}$ in diameter) in conjunction with a fixed frequency (50 $\mathrm{c} / \mathrm{s})$ a.c. sine wave stimulator. The depth of probe insertion $(21-26 \mathrm{~cm})$, the voltage $(0.5-2.0 \mathrm{~V})$ and the period of stimulation (4 sec stimulation/4 sec rest) were varied to induce the emission of several fractions of semen with a total volume of 1-2 ml and a sperm concentration of between $2-4 \times 10^{7} / \mathrm{ml}$ (mean $3.2 \times 10^{7} / \mathrm{ml}$ ). Since spermatozoa in seminal plasma rapidly lost motility, semen fractions containing spermatozoa of good progressive motility $(>60 \%)$ were centrifuged at $700 \mathrm{~g}$ for $5 \mathrm{~min}$ and then resuspended in $0.5 \mathrm{ml}$ Tyrode's solution, $\mathrm{pH} 7.5,320 \mathrm{mosmol}$ (see Lillie \& Fullmer, 1976) to give a final sperm concentration of $2-4 \times 10^{7} / \mathrm{ml}$. This sperm suspension was kept in an incubator at $37^{\circ} \mathrm{C}$ in a $1 \mathrm{ml}$ sterile syringe. Good sperm motility was observed with this preparation up to the time of insemination.

Insemination. For each female, two intrauterine inseminations were carried out at approximately 20 and $40 \mathrm{~h}$ after hCG injection. The reproductive tract was exposed by midline laparotomy and $0.2 \mathrm{ml}$ sperm suspension was injected into each uterine horn near to the utero-tubal junction. The time taken from semen collection to insemination was less than $30 \mathrm{~min}$.

\section{Radioimmunoassay of steroids}

Progesterone was measured by a method reported in detail elsewhere (Bonney, Dixson \& Fleming, 1979) using an antiserum (465/6 from Dr B. J. A. Furr) raised in a goat to progesterone-1 $1 \alpha$-succinyl-bovine serum albumin. Cross-reactivity with the majority of $\mathrm{C} 18$ and C19 steroids tested was less than $0.1 \%$. Of the $C 21$ steroids tested, $5 \alpha$ - and $5 \beta$-pregnane3,20 -dione cross-reacted significantly $(35.3$ and $2.5 \%$ respectively), as did $11 \beta$-hydroxypregn-4-ene-3,20-dione $(35 \%)$ but the extraction procedure adopted in the assay eliminated possible interference by the latter steroid. In the present study, $100 \mu$ l undiluted plasma were used for each extraction. Inter- and intra-assay coefficients of variation, as established by repeated assay of a plasma pool in a single assay and in separate assays, were $5 \cdot 11$ and $10 \cdot 57 \%(n=10)$ respectively. Buffer blanks were extracted with each assay and were usually less than the sensitivity of the assay $(11.0 \pm 0.4 \mathrm{pg} /$ tube, $n=11)$. A correction was included when the buffer blank exceeded this value. Procedural losses were determined and corrected for in each assay by the recovery of $\left[{ }^{3} \mathrm{H}\right]$ progesterone added to a pool of plasma (mean recovery for 10 assays: 71.7 $\pm 3 \cdot 6 \%$ ).

Oestradiol-17 $\beta$ was measured using a specific antiserum (ES2) raised in a rabbit to oestradiol-17ß-6-0-carboxymethyl-oxime-bovine serum albumin (Miles Laboratories Ltd, Slough, Bucks, U.K.). Cross-reactions with other oestrogens were: oestrone, $0.35 \%$; oestriol, $0.29 \%$; oestradiol- $17 \alpha, 0.72 \%$. Duplicate aliquots of plasma (usually $1.0 \mathrm{ml}$ ) were extracted for $45 \mathrm{sec}$ with $10 \mathrm{ml}$ freshly distilled diethyl ether (BDH 'Analar': Poole, Dorset, U.K.). The aqueous layer was then frozen in an acetone/liquid nitrogen bath and the organic phase decanted into glass bottles and evaporated to dryness. The residues were dissolved in $0.5 \mathrm{ml}$ acetone of which $0.4 \mathrm{ml}$ was transferred to $12 \times 75 \mathrm{~mm}$ glass assay tubes, evaporated to dryness, and then reconstituted in $100 \mu \mathrm{l}$ assay buffer $(0.1 \mathrm{~m}$-phosphate, $\mathrm{pH} 7 \cdot 0$, containing $0.9 \%(\mathrm{w} / \mathrm{v}) \mathrm{NaCl}$, $0.01 \%$ thimerosal and $1 \%$ gelatin). The assay was then completed according to methods previously reported (Bonney et al., 1979, 1980). The radioligand employed was $12,4,6$, $7(\mathrm{n})-{ }^{3} \mathrm{H}$ loestradiol-17 $\beta$ (sp. act. $86 \mathrm{Ci} / \mathrm{mmol}$ : Radiochemical Centre, Amersham, Bucks, U.K.). The standard curve ranged from 1000 to $3.9 \mathrm{pg} /$ tube and the sensitivity of the assay was $3.52 \pm$ $0.32 \mathrm{pg} /$ tube $(n=11)$. Procedural losses were determined and corrected for in each assay by the recovery of $\left[{ }^{3} \mathrm{H}\right]$ oestradiol- $17 \beta$ added to a pool of puma plasma (mean recovery for 10 assays: $89.6 \pm 2 \cdot 62 \%)$. Inter- and intra-assay coefficients of variation were $10 \cdot 1 \%(n=10)$ and $8 \cdot 26 \%$ 
$(n=11)$, respectively. A correction was made for buffer blanks when they exceeded the sensitivity of the assay.

\section{Results}

\section{Oestrus}

Plasma profiles of oestradiol and progesterone during oestrus in the 3 females are shown in Text-fig. 1.

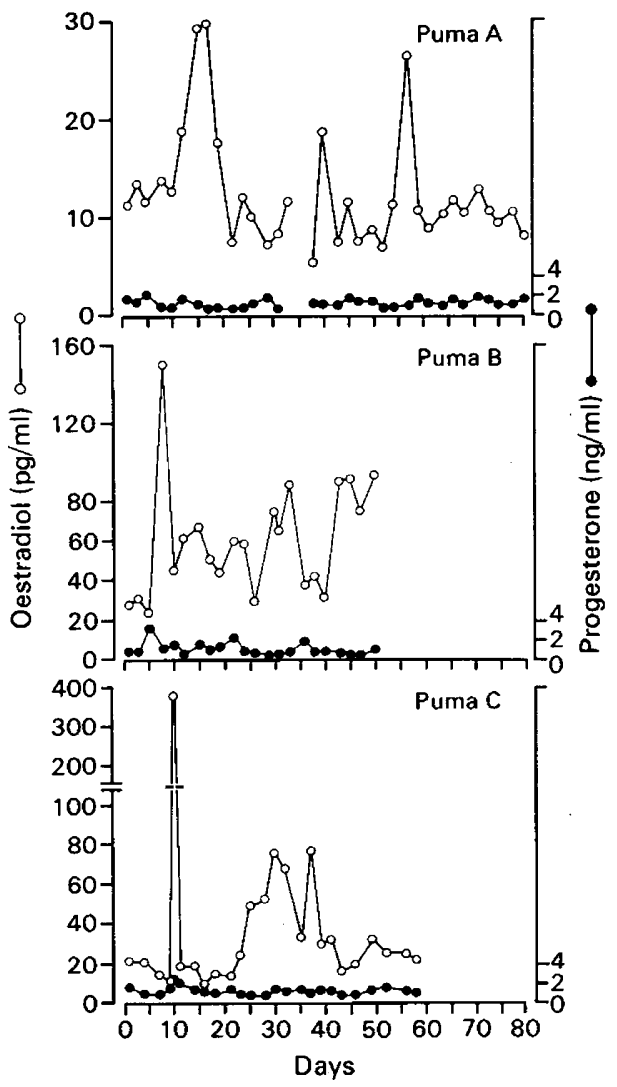

Text-fig. 1. Changes in concentrations of plasma oestradiol $(0)$ and progesterone $(0)$ in 3 individual pumas during oestrus.

\section{PLATE 1}

Fig. 1. An ovary at the time of natural oestrus (Puma B). The follicles (arrowed) on the ovarian surface are considerably larger than at dioestrus (see Fig. 2).

Fig. 2. An ovary during dioestrus (Puma A). At this stage the ovary has a pale appearance while follicles (arrowed) are small and often atretic.

Figs 3-5. Induction of ovulation in Puma B. Fig. 3. Right ovary $19 \mathrm{~h}$ after hCG injection; 2 preovulatory follicles (arrowed) can be seen. Fig. 4. Left ovary $35 \mathrm{~h}$ after hCG, showing a recently ruptured follicle (arrowed). Fig. 5. The left ovary with a corpus luteum (arrowed) 11 days after hCG.

Fig. 6. An ovary at Day 40 of pseudopregnancy (Puma B). The corpora lutea (arrowed) have regressed. 
$P[+1\}$
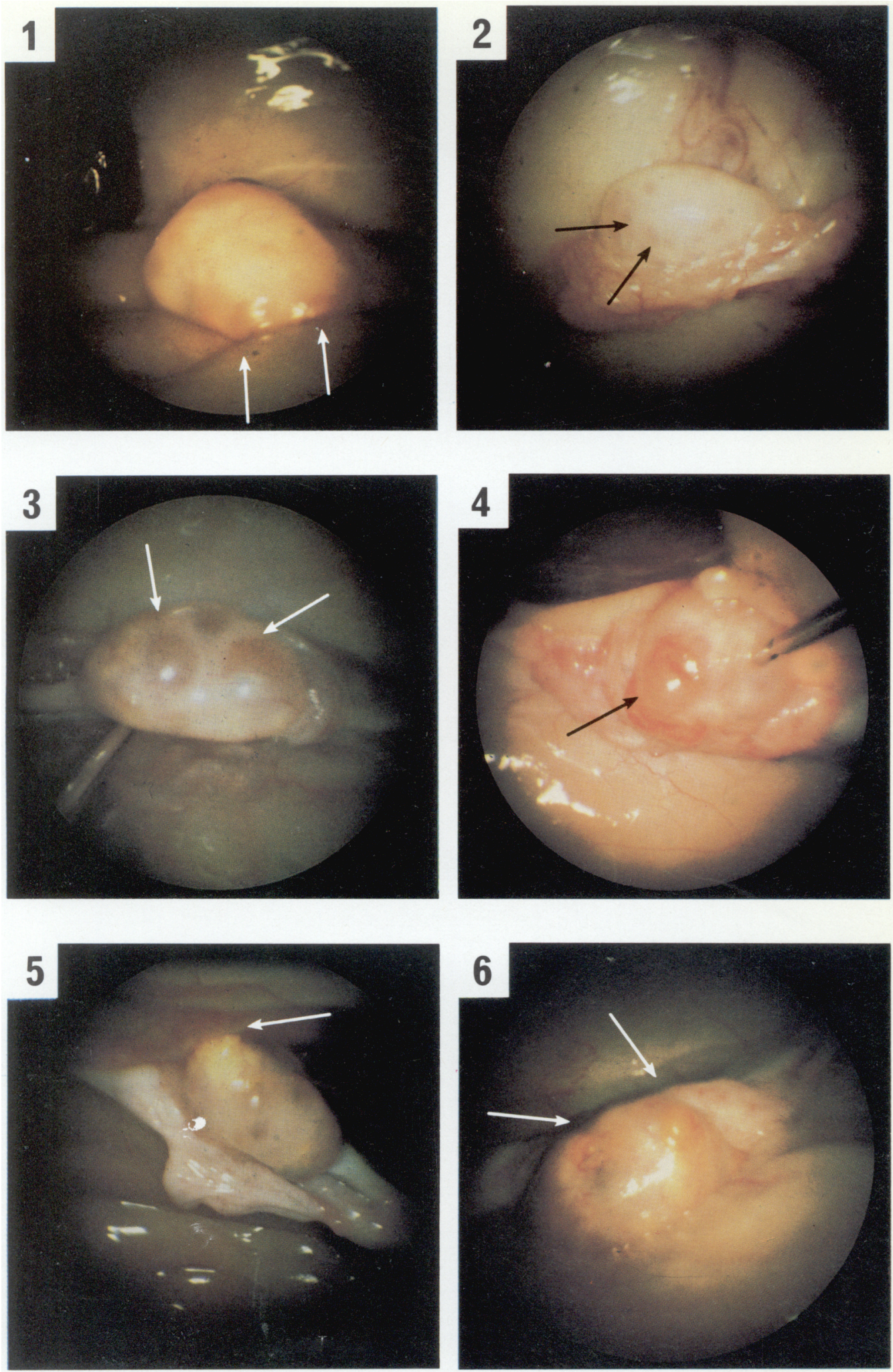

Downloaded from Bioscientifica.com at 04/26/2023 08:17:16AM via free access 
Basal concentrations of 5-30 pg oestradiol $/ \mathrm{ml}$ were interrupted by intermittent peaks at intervals of 17-25 days. In Puma $A$ baseline levels were of the order of $5-10 \mathrm{pg} / \mathrm{ml}$ and peak values did not exceed $30 \mathrm{pg} / \mathrm{ml}$ (Days 17, 40 and 57). However, in Puma B basal levels were considerably higher $(20-40 \mathrm{pg} / \mathrm{ml})$ and peak concentrations of $80-150 \mathrm{pg} / \mathrm{ml}$ (Days 8,33 and 50) were measured. Oestradiol surges of 80 and $375 \mathrm{pg} / \mathrm{ml}$ were recorded for Puma C (Days 10, 30 and 37). These data demonstrate the considerable variation in amplitude and frequency of the surges both with and between individual animals.

Concentrations of progesterone in peripheral plasma rarely exceeded $2 \mathrm{ng} / \mathrm{ml}$ and at no time was an oestradiol peak followed by an elevation in plasma progesterone.

The pattern of cornified cells in vaginal smears indicative of oestrus in the cat (Herron, 1977) was most prevalent during or immediately after high levels of plasma oestradiol, while the presence of intermediate and parabasal cell types was generally correlated with low oestradiol concentrations.

Ovaries examined by laparoscopy during oestrus exhibited several secondary follicles (P1. 1, Fig. 1) although these did not protrude to any extent from the surface of the ovary. In dioestrus, follicular development was less marked and ovaries displayed atretic and primary follicles (PI. 1, Fig. 2). At no time during oestrus were corpora lutea observed.

\section{Pseudopregnancy}

In Puma B (Studies 1 and 2) ovulation occurred 24-40 h after the hCG injection but in Puma $\mathrm{C}$ (Study 3 ) two injections of hCG were required to induce ovulation 4 days after the first and 48 $\mathrm{h}$ after the second injection of hCG. The precise time of ovulation was determined by laparoscopy performed several times after hCG injection. A typical pattern of follicular development, ovulation and formation of corpora lutea is shown in Pl. 1, Figs 3-5 for Puma B. At $19 \mathrm{~h}$ after hCG injection several preovulatory follicles were present in each ovary (Pl. 1, Fig. 3). These were translucent, raised from the ovarian surface and more pronounced than during natural oestrus (compare Pl. 1, Figs 1 and 3). The rupture of several follicles $35 \mathrm{~h}$ after hCG indicated ovulation (Pl. 1, Fig. 4) and an examination 11 days after hCG revealed large corpora lutea projecting from the ovarian surface (Pl. 1, Fig. 5). A mean of 3.5 ovulations (range $2-6$ ) occurred with this induction procedure. By 40 days after ovulation the corpora lutea had regressed (Pl. 1, Fig. 6).

The administration of PMSG caused a rapid increase in circulating levels of oestradiol from $10-30 \mathrm{pg} / \mathrm{ml}$ to reach maximum values of $200-300 \mathrm{pg} / \mathrm{ml}$ followed by a fall to basal levels by Day 10, although in Puma $C$ the decline was more gradual and concentrations remained elevated until Day 24 (Text-fig. 2). In Puma B (Study 1) oestradiol values were consistently low (10-20 $\mathrm{pg} / \mathrm{ml}$ ) until Day 75 when an increase indicated the onset of follicular activity. Patterns of plasma oestradiol in Pumas B (Study 2) and C were more variable; however, oestradiol surges of 60 $\mathrm{pg} / \mathrm{ml}$ on Days 50 and 82 in Puma $C$ were associated with the vocalization behaviour indicative of oestrus in this species (Rabb, 1959).

Before ovulation, progesterone levels were low $(<2 \mathrm{ng} / \mathrm{ml})$ but maximum concentrations of $150-300 \mathrm{ng} / \mathrm{ml}$ were reached on Days $24-28$, before declining to baseline levels by Days $45-50$ and remaining low $(<2 \mathrm{ng} / \mathrm{ml})$.

\section{Pregnancy}

Intrauterine insemination following artificial induction of ovulation resulted in a successful pregnancy in Puma A and a single live birth within 95 days of hCG administration. The patterns of plasma oestradiol and progesterone concentrations during this pregnancy are illustrated in Text-fig. 3. The hormonal response to PMSG and hCG was essentially similar to that in Pumas $\mathrm{B}$ and $\mathrm{C}$ during pseudopregnancy. 


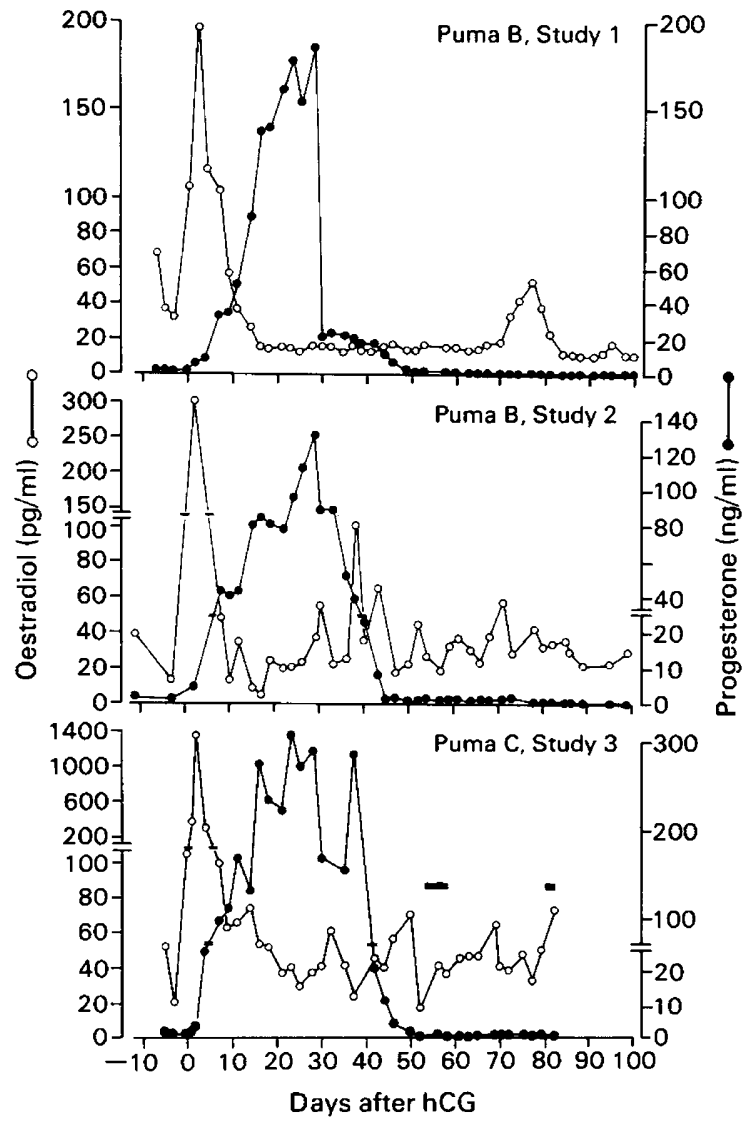

Text-fig. 2. Profiles of plasma oestradiol (O) and progesterone (O) in Pumas B (Studies 1 and 2) and C (Study 3) after induction of ovulation with PMSG (Day 3) and hCG (Day 0) and throughout pseudopregnancy. Ovulation occurred at 30-40 h (Study 1) and 24-40 h (Study 2) after a single hCG injection. Puma C (Study 3) required a second injection of hCG (Day 2) to induce ovulation on Day 4. Vocalization behaviour in Puma $\mathrm{C}$ is indicated by black bars.

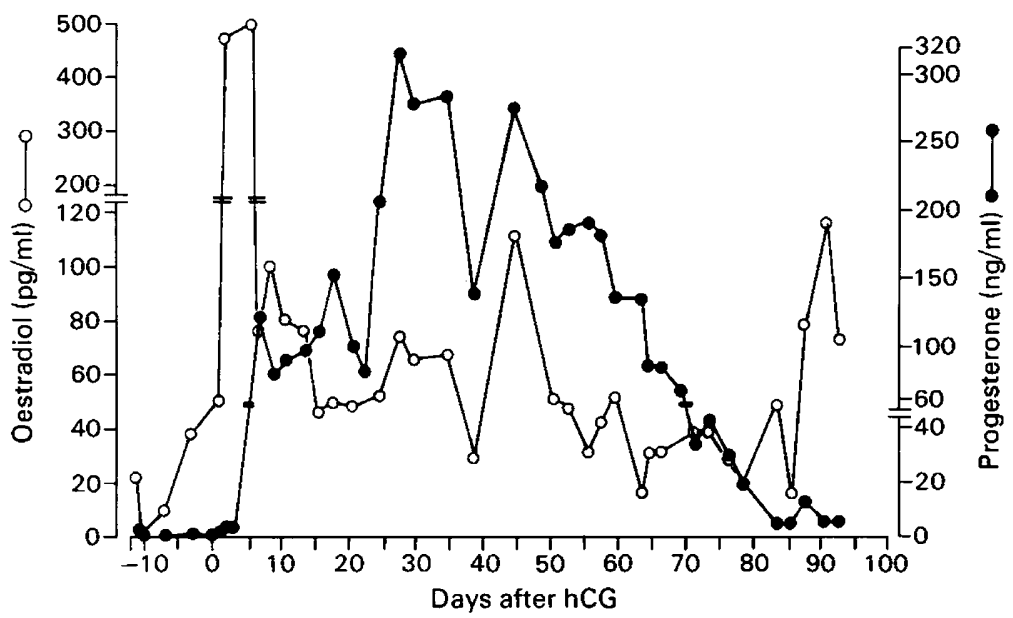

Text-fig. 3. Plasma oestradiol (O) and progesterone (O) concentrations in Puma A during pregnancy after induction of ovulation with PMSG (Day 3) and hCG (Day 0) and artificial insemination on Days 1 and 3. Ovulation occurred on Day 3 and parturition on Day 95. 
Plasma concentrations of oestradiol increased from $39 \mathrm{pg} / \mathrm{ml}$ at the time of PMSG injection to $500 \mathrm{pg} / \mathrm{ml} 3$ days following hCG treatment and then declined to $43 \mathrm{pg} / \mathrm{ml}$ on Day 16 . Thereafter, plasma levels varied between 15 and $70 \mathrm{pg} / \mathrm{ml}$ throughout pregnancy with the exception of two major peaks of $110 \mathrm{pg} / \mathrm{ml}$ which occurred at mid-pregnancy (Day 45) and immediately before parturition (Day 91). Both peaks were associated with a rise in plasma progesterone levels.

Circulating levels of progesterone remained at $<4 \mathrm{ng} / \mathrm{ml}$ during the first 3 days after hCG injection but then rose rapidly to reach a maximum of $320 \mathrm{ng} / \mathrm{ml}$ on Day 28 . The subsequent decrease to $120 \mathrm{ng} / \mathrm{ml}$ on Day 39 was comparable to that observed in the pseudopregnant animals. However, by Day 45 and coincident with the mid-pregnancy surge of oestradiol, plasma levels of progesterone had increased to $280 \mathrm{ng} / \mathrm{ml}$. A gradual decline then followed until by Day 85 plasma concentrations had returned to baseline. A further small elevation $(12 \mathrm{ng} / \mathrm{ml})$ on Day 88 was associated with the pre-partum surge of oestradiol.

As a precaution against abortion, laparoscopic examination of the pregnant animal was avoided once ovulation had been confirmed.

\section{Discussion}

During oestrus, basal levels of oestradiol varied considerably between the three animals in the study. Similarly, there was variation in the maximum level of oestradiol attained during the oestrous surge. However, the present values compare well with basal oestradiol levels of 5-15 $\mathrm{pg} / \mathrm{ml}$ and peak levels of $30-70 \mathrm{pg} / \mathrm{ml}$ for the cat (Verhage et al., 1976) and 5-10 pg/ml (basal) and $20-108 \mathrm{pg} / \mathrm{ml}$ (peak) levels obtained for the lion (Schmidt et al., 1979).

Although there was a greater proportion of cornified cells in vaginal smears taken from pumas during oestrus while intermediate and parabasal cell types were more numerous during the interoestrous period, the identification of oestrus solely from the examination of vaginal smears was not sufficiently reliable for routine use. Schmidt et al. (1979) also observed higher proportions of cornified cells in vaginal smears taken immediately following an increase in serum oestradiol in lions, but the cytological differences throughout the rest of the cycle were not sufficiently distinct to be of practical value.

In the domestic cat the interoestrous period is approximately 16 days (Verhage et al., 1976). In the present study the frequency of oestradiol surges varied between 17 and 25 days which made the interpretation of the data difficult. Although this was in part probably due to the limitations imposed by the sampling regimen and may have been influenced by the stress of handling and anaesthesia, such irregularity among felids is not uncommon judging by behavioural observations (lion: Eaton, 1974; tiger: Kleiman, 1974) and hormonal measurements (lion: Seal et al., 1978).

Concentrations of plasma progesterone did not exceed $2 \mathrm{ng} / \mathrm{ml}$ during the period of oestrus, which compares with levels of $<1 \mathrm{ng} / \mathrm{ml}$ reported for the domestic cat (Verhage et al., 1976). The absence of a rise in circulating levels of progesterone following a surge of oestradiol indicated that spontaneous ovulation had not occurred, which suggests that the puma is an induced ovulator. This was confirmed by the lack of luteal development. Wildt et al. (1979) noted the absence of luteal tissue during the oestrous cycle of one jaguar. In contrast, Schmidt et al. (1979), in their study of the oestrous cycle of 3 lionesses, frequently measured peaks of progesterone of up to $280 \mathrm{ng} / \mathrm{ml}$ immediately following a surge of oestradiol, suggesting spontaneous ovulation.

In the present study the administration of PMSG stimulated a more pronounced development of the ovarian follicles than was observed during natural oestrus and elicited a dramatic rise in plasma oestradiol within 5 days of treatment. These observations suggest that the dose of PMSG used may have caused over-stimulation of the ovaries although a mean ovulation rate of 3.5 and the birth of a single cub to the pregnant animal (normal litter size 1-5: Robinette, Gashwiler \& 
Morris, 1961) indicate that this was unlikely. However, PMSG treatment may have stimulated the development of a number of follicles which did not ovulate and since data from natural matings are not available for this species this possibility cannot be precluded.

A dose of 1000 i.u. hCG was effective in triggering ovulation on each occasion although in Puma $\mathrm{C}$ a second injection was required. However, the initial injection may have failed due to insufficient absorption of hormone from the selected site. The time interval from administration of hCG to ovulation (1-3 days) compares with the interval from coitus to ovulation reported for the cat. Paape et al. (1975) estimated the time from first coitus to ovulation to be 1-3 days while Shille \& Stabenfeldt (1979) confirmed ovulation within $30 \mathrm{~h}$ post coitum.

The duration of pseudopregnancy was 45-50 days which was approximately half the length of the full-term pregnancy. A similar time relationship occurs in the domestic cat in which pseudopregnancy lasts about 30 days and the gestation period is 65 days (Verhage et al., 1976). Lower levels of progesterone were measured during pseudopregnancy than in pregnancy in the domestic cat (Verhage et al., 1976) but insufficient data preclude a similar comparison for the puma.

In the domestic cat regressive luteal changes are first detected at around Days 21-28 (Foster \& Hisaw, 1935; Dawson, 1950). A decline in progesterone levels due to regression of the corpora lutea (Pl. 1, Fig. 6) occurs in the puma between Days 30-40 which is proportionately similar to the time of luteal regression in the domestic cat. During pregnancy in the puma, the progesterone profile suggests the start of luteal regression but a subsequent rise on Day 45 followed by a steady decline to baseline by Day 85 indicates placental synthesis of progesterone or heightened function of the corpora lutea of pregnancy. A similar pattern of progesterone secretion was reported for the lion during pregnancy (Schmidt et al., 1979).

The re-establishment of ovarian activity after pseudopregnancy coincided, on two occasions, with rapidly declining progesterone levels between Days 39 and 48. In Puma B (Study 1), however, there were no signs of oestrus until Day 75 although progesterone levels had returned to baseline by Day 50. Variation in the time to onset of first oestradiol surge following pseudopregnancy in the domestic cat has been attributed to differences between animals in the rate of luteal regression and consequent decline in progesterone secretion (Verhage et al., 1976). Although a similar explanation might be valid for the present study, progesterone concentrations in Puma B (Study 1) had returned to baseline 25 days before a peak of oestradiol was detected and in this instance it seems likely that other factors were involved.

The pattern of oestradiol concentrations during pregnancy resembles that described for the domestic cat (Verhage et al., 1976). The mid-pregnancy surge of oestradiol in the puma has not been reported for the domestic cat, but a pre-partum surge has been recorded for both (Verhage et al., 1976). Furthermore, a minor elevation in plasma progesterone which was measured at the same time as the oestrous surge in the puma was not found in the domestic cat (Verhage et al., 1976). These events are probably associated with rapidly changing endocrine activity following the decline of the corpus luteum and prior to the onset of parturition. The pre-partum period merits further investigation since hormonal changes could provide a useful indicator of the onset of parturition and an aid to the management of breeding in captivity.

The present study demonstrates a similarity between the puma and the domestic cat with respect to the hormonal patterns in recurrent oestrus, pseudopregnancy and pregnancy. It provides a good basis on which to expand our knowledge of felid reproduction and to establish artificial breeding programmes for related endangered species.

We thank Richard Wolf Ltd for the loan of laparoscopic equipment and the U.K. representative, $\mathrm{Mr}$ T. Northwood, for his invaluable advice; Bayer U.K. Ltd and Parke Davis for gifts of xylazine and ketamine, respectively; Miss D. Wood and $\mathrm{Mr} \mathrm{T}$. Hartman for excellent technical assistance; Mr G. Nevill for his participation in the early stages of the project; and the staff of the Animal Hospital for the collection of blood samples and maintenance of the animals. 


\section{References}

Bonney, R.C., Dixson, A.F. \& Fleming, D. (1979) Cyclic changes in the circulating and urinary levels of ovarian steroids in the adult female owl monkey (Aotus trivirgatus). J. Reprod. Fert. 56, 271-280.

Bonney, R.C., Dixson, A.F. \& Fleming, D. (1980) Plasma concentrations of oestradiol-17ß, oestrone, progesterone and testosterone during the ovarian cycle of the owl monkey (Aotus trivirgatus). $J$. Reprod. Fert. 60, 101-107.

Concannon, P., Hodgson, B. \& Lein, D. (1980) Reflex $\mathbf{L H}$ release in estrous cats following single and multiple copulations. Biol. Reprod. 23, 111-117.

Dawson, A.B. (1950) The domestic cat. In Care and Breeding of Laboratory Animals, pp. 202-233. Ed. E. J. Farris. John Wiley \& Sons, New York.

Eaton, R.L. (1974) The biology and social behavior of reproduction in the lion. In The World's Cats, Vol. II. Biology, Behavior and Management of Reproduction, pp. 3-58. Ed. R. L. Eaton. Feline Research Group, Seattle.

Foster, M.A. \& Hisaw, F.L. (1935) Experimental ovulation and resulting pseudopregnancy in anestrous cats. Anat. Rec. 62, 75-93.

Greulich, W.W. (1934) Artificially induced ovulation in the cat (Felis domestica). Anat. Rec. 58, 217-224.

Herron, M.A. (1977) Feline vaginal cytologic examination. Feline Practice 7, 36-38.

Kleiman, D.G. (1974) The estrous cycle in the tiger. In The World's Cats, Vol. II. Biology, Behavior and Management of Reproduction, pp. 60-75. Ed. R. L. Eaton. Feline Research Group, Seattle.

Lillie, R.D. \& Fullmer, H.M. (1976) Histopathologic Technic and Practical Histochemistry, McGraw-Hill Inc., New York.

Paape, S.R., Shille, V.M., Seto, H. \& Stabenfeldt, G.H. (1975) Luteal activity in the pseudopregnant cat. Biol. Reprod. 13, 470-474.

Rabb, G.B. (1959) Reproductive and vocal behavior in captive pumas. J. Mammal. 40, 616-617.
Robinette, W.L., Gashwiler, J.S. \& Morris, O.W. (1961) Notes on cougar productivity and life history. $J$. Mammal. 42, 204-217.

Rowlands, I.W. \& Sadleir, R.M.F.S. (1968) Induction of ovulation in the lion, Panthera leo. J. Reprod. Fert. 16, 105-111.

Schmidt, A.M., Nadal, L.A., Schmidt, M.J. \& Beamer, N.B. (1979) Serum concentrations of oestradiol and progesterone during the normal oestrous cycle and early pregnancy in the lion (Pathera leo). J. Reprod. Fert. 57, 267-272.

Seal, U.S., Plotka, E.D. \& Gray, C.W. (1978) Baseline hematology, serum chemistry and hormone data for captive tigers (Panthera tigris spp.) and lions ( $P$. leo). In International Tiger Studbook: Congress report on 1st International Symposium on the Management and Breeding of the Tiger, pp. 174-192. Zoologischer Garten Leipzig.

Shille, V.M. \& Stabenfeldt, G.H. (1979) Luteal function in the domestic cat during pseudopregnancy and after treatment with prostaglandin F2a. Biol. Reprod. 21, 1217-1223.

Shille, V.M., Lündstrom, K.E. \& Stabenfeldt, G.H. (1979) Follicular function in the domestic cat as determined by estradiol-17 $\beta$ concentrations in plasma: relation to estrous behavior and cornification of exfoliated vaginal epithelium. Biol. Reprod. 21, 953-963.

Verhage, H.G., Beamer, N.B. \& Brenner, R.M. (1976) Plasma levels of estradiol and progesterone in the cat during polyestrus, pregnancy and pseudopregnancy. Biol. Reprod. 14, 579-585.

Wildt, D.E., Kinney, G.M. \& Seager, S.W.J. (1978) Gonadotropin induced reproductive cyclicity in the domestic cat. Lab. Anim. Sci. 28, 301-307.

Wildt, D.E., Platz, C.C., Chakraborty, P.K. \& Seager, S.W.J. (1979) Oestrus and ovarian activity in a female jaguar (Panthera onca). J. Reprod. Fert. 56, 555-558.

Received 31 December 1980 